\title{
Amr Kamal
}

\section{GHOSTLY LABOR: ETHNIC CLASSISM IN THE LEVANTINE PRISM OF JACQUELINE KAHANOFF'S JACOB'S LADDER}

\begin{abstract}
In her writings, the Egyptian-born Israeli author Jacqueline Shohet Kahanoff advocated Levantine cosmopolitanism, which she dubbed Levantinism, as a unique cultural model particular to the Eastern Mediterranean. Through an analysis of Kahanoff's novel Jacob's Ladder (1951), this article questions the nostalgic image often associated with Egyptian cosmopolitanism. I argue that this text provides rare insight into the process through which Levantine culture developed amid several competing imperial and nationalist projects. In particular, I show how the novel's depiction of Levantine spaces documents the marginalized role of the working class in the education of elite Levantine society and its acquisition of cultural capital. My analysis also explores how the construction and sustenance of a celebrated image of the Levantine past depended on the racialization of labor, or what I call "ethnic classism." Through this latter process, a labor force made up of other cosmopolitan subjects was Orientalized and relegated to the background where it served to highlight a European-like Levantine cosmopolitanism.
\end{abstract}

Keywords: cosmopolitanism; department stores; ethnic classism; Levantine culture; Mizrahi literature

It was while the baby greedily clung to Amina's big breast that arrangements were made.

"What will you do with your own child?" Alice nervously asked her.

Jacob's Ladder, Jacqueline Shohet Kahanoff

In her semiautobiographical English novel Jacob's Ladder (1951), Jacqueline Kahanoff recounts the social ascension of the Gaons, a Jewish family residing in Egypt. ${ }^{1}$ At one point in the story, after the birth of their second child, Alice and David Gaon search for a wet nurse to feed their weak son. Eventually they come across Amina, a poor Syrian Christian woman whom they describe as "clean, strong, healthy, [and] honest. Her milk is so good . . . it would revive a corpse!"2 While interviewing her, Alice anxiously asks Amina what she would do with her own child if she were to accept the job and move in with the family. ${ }^{3}$ This tension-ridden moment in the scene suggests that the employment arrangement was tantamount to an exchange of both children's fate,

Amr Kamal is an Assistant Professor of French, Arabic, and Comparative Literature in the Department of Classical and Modern Languages and Literatures, The City College of New York, City University of New York, New York, N.Y.; e-mail: akamal@ccny.cuny.edu

(C) Cambridge University Press 2017 0020-7438/17 
especially given that later in the story Amina's son dies of malnutrition due to his mother's absence. In an almost Darwinian sense, the text underscores the interdependence of two Levantine worlds, with elite Levantines feeding off their working-class Other.

This article focuses on representations of class in Jacob's Ladder. Through a reading of the novel, I connect the origins of Levantine culture to one of the many instances in which social classes were shaped at the crossroads of myriad imperial projects and spheres of influence that was colonial Egypt. Examining Levantine culture's spaces of production, I demonstrate the often-marginalized role of working-class Levantines in the elites' acquisition of culture capital and consolidation of their status. Moreover, I highlight the implicit racial and class tensions that underlay the romanticized memory of a bourgeois Levantine past that became dominant in post-1960s memoirs and novels. ${ }^{4}$ This frequently invoked memory was produced through the racialization of labor, or what I term "ethnic classism," which accentuated the difference between the upper and working classes. A European and Arab labor force was Orientalized to construct a contrasting Europeanized cosmopolitan image of Levantine elites.

Jacob's Ladder narrates the coming of age of Rachel Gaon, a young Jewish girl from Egypt who is the granddaughter of two mercantile patriarchs: the wise Jacob Gaon, who migrated to Egypt from Iraq and founded a successful business enterprise, and the lively and hardworking Nathan Smadja, who migrated to Egypt from Tunisia and established a department store called Smadja Brothers in Cairo. The title of the novel refers to a passage in Genesis where Jacob is advised to leave his hometown and settle in Haran. During his journey, he dreams of a ladder descending from heaven that connects him to God, who reassures him of his future. ${ }^{5}$ Kahanoff uses this biblical story as an allegory for Rachel's family members, who after leaving behind their respective homelands seek reassurance through the consolidation of their social and economic position in Egypt. Growing up in colonial Cairo, Rachel struggles to reconcile her diverse "Arab Jewish" heritage bridging the Mashriq and the Maghreb, the East and West of the Arab world, and her European education. She does not identify as Egyptian, but neither does she see herself as fitting in to the British and French cultures that her British governesses and French school respectively uphold. Although the novel presents Rachel Gaon's identity crisis as an adolescent dilemma, her impasse nevertheless reveals the complicated position of Egyptian Jews during the interwar period as they navigated an intricate web of ethnic and class relations linked inherently to Egyptian nationalism and French and British colonialism. ${ }^{6}$

\section{MEMORY OF A LEVANTINE WORLD}

Similar to the protagonist in her novel, Jacqueline Kahanoff was born in Cairo into an Iraqi and Tunisian Jewish family. Her Tunisian maternal grandparents, the Chemlas, founded the renowned Chemla department store in central Cairo, which still operates under its original name despite a change of ownership in 1946 and its nationalization in $1956 .^{7}$ Kahanoff bases parts of her novel on the early history of that store, which she presents as a key site of her protagonist's instruction in Levantine culture. In 1940, after her marriage, Kahanoff left Egypt for San Francisco. Two years later she separated from her husband and settled in New York, where she completed her undergraduate studies and then a master's degree in journalism at Columbia University. While in New York, 
and during time spent in London, she also wrote Jacob's Ladder. In 1951 she joined her sister in Paris where she experimented writing in French and met her second husband, Alexander Kahanoff, with whom she settled in Israel in 1954. ${ }^{8}$ Jacqueline Kahanoff's trajectory is emblematic of a postcolonial subject who experienced the transition from empire to nation-state. Significantly, she wrote only in the language of the former empires, in her case English and French, and never in that of the nation, in her case Arabic and Hebrew, her spoken languages, even though she had studied formal Arabic during her stay in France and Hebrew as an adult in Israel. ${ }^{9}$

Throughout her life, Jacqueline Kahanoff encountered various pejorative views of Levantine culture, which made it increasingly difficult for her to come to terms with it as a unique, multiethnic, and multicultural lifestyle. From a British perspective, derived from Lord Cromer's memoir Modern Egypt, the word "Levantine" was mainly associated with Francophiles and bore the stigma of dangerous hybridity, comprising a medley of European and Near Eastern cultures in contrast to the homogenous national cultures of Western Europe. ${ }^{10}$ The French view, evident in travelogues and fiction, was similarly derogative, often depicting Levantines as ambiguous, drifting, or middlemen engaged in questionable activities. ${ }^{11}$ In Israel, advocates of Zionism considered Levantinism, with its connections to Arab culture, a corruption of national identity from which the nation must be saved. ${ }^{12}$ This discourse sought to undermine not only Levantinism, but also the broader experience and history of Arab Jews. As Ella Shohat argues, within the national and cultural paradigms of both Israeli and Arab nationalism, the identification "Arab Jew" became "an oxymoronic entity." Cast as outsiders amid the currents of Pan-Arabism, Arab nationalism, and Zionism, Arab Jews experienced simultaneous geographical and cultural "dislocation" and "displacement." 13 After facing social and political pressure to leave their countries of origin, those who settled in Israel were forced to suppress their memories of the Arab world due to how these memories contradicted the foundational Ashkenazi Zionist narrative of exile and return (depicted in Zionist discourse as a journey from "diaspora to redemption"). ${ }^{14}$ As Shohat points out, in its approach to Arab Jews, Zionism adapted a colonial perspective of race and class to produce what she describes as "Zionist Orientalism." 15 The depiction of Arab Jews in reductive Orientalist terms and the constant association of them with manual labor regardless of background foreclosed the possibility of recognizing Arab Jewish heritage, including Levantine culture, in any positive way. ${ }^{16}$

In this complex cultural and political context within Israel, Kahanoff presented colonial Cairo and Alexandria as a social model in order to reclaim the Levantine experience as a unique lifestyle, which she referred to as "Levantinism." "17 Against disparaging colonial perceptions of the Eastern Mediterranean, she argued for the acceptance of an independent Levantine culture with its own value system and aesthetics. In her most widely celebrated quote, she defines the Levant, including Egypt, as "not exclusively eastern or western, Christian, Jewish, or Moslem. . . . It is more like a prism whose various facets are joined by a sharp edge of differences." 18 For Kahanoff, these differences were cultural, religious, and ethnic. But one wonders whether, as the epigraph of this article indicates, they were also class based.

Addressing the institutional and social bias in the representation of Levantine and Mizrahi cultural production, Ammiel Alcalay has critiqued the paucity of circulated literary and academic texts attending to the contributions of Mizrahi Jews to Arab and 
Israeli cultures, which complicate the standard tropes and binaries often deployed in political and cultural representations of the Middle East. ${ }^{19}$ Since then, many works, especially memoirs, in Arabic, Hebrew, English, and French have been published to document, and in some cases come to terms with, the cosmopolitan life and Levantine culture of colonial Egypt and other parts of the Near East. These texts cover the experiences of a wide range of communities, including the dislocation of Arab Jews from various Arab countries and their migration to different regions of the world, including Israel. ${ }^{20}$ Most of the widely known representations of Levantine culture, however, come from Francophone middle-class or elite authors such as Jacqueline Kahanoff who possess the agency to document their experiences. As a result, these representations have perpetuated the common association of Levantinism with the image of a rootless Francophile socialite. ${ }^{21}$

A number of recent academic works have analyzed such literary texts in order to explore Levantinism as an active space of cultural production and cultural memory that challenges reductive notions of Jewish and Arab identity articulated in Zionist and Arab nationalist discourse. ${ }^{22}$ In prioritizing this perspective, however, they overlook to an extent the actual material history, including social and colonial dynamics, that led to its construction. Much remains to be said about the origins of Levantinism, the agents who participated in its production, and the "politics of memory" that contributes to its current framing. Scholarship in history, literature, and cultural studies has questioned the historical validity of the romanticized image of a homogenous Francophile cosmopolitan society most common in literary narratives about Alexandria. ${ }^{23}$ This scholarship shows that, opposite this representation, the Levantine community, including Egyptian Jews, was divided by culture, social class, and geographic origins. ${ }^{24}$

In this article, I show how this celebrated image depended on the invisible labor of other Levantines from the working class who helped their employers acquire economic and cultural capital. Though often unnoticed, the literary texts in question contain a recurring motif of domestic workers and other working-class laborers from different ethnic communities-including Greeks, Italians, Syrians, Lebanese, Sudanese, Egyptians, and others. It is often through domestics that the protagonists of these works define their ties to their immediate surroundings. Servants also play the role of parental figure, informal teacher of Arabic, Orientalized representative of local culture, and even keeper of memory for the Levantine employer who departed, either voluntarily or involuntarily, as part of the broader dislocation of many ethnic communities in the late $1950 \mathrm{~s}^{25}$ Yet despite their diverse cultural backgrounds and important roles, servants appear in these texts only as a ghostly presence or fleeting reference. Rather than being an important part of the bygone, bourgeois, or middle-class cosmopolitan life described by the narrator, they serve merely as the backdrop of that image.

The elitist framing of Levantine cosmopolitanism thus enacts an implicit erasure, what Pierre Bourdieu calls "genesis amnesia," when a final image of a social class is severed from its origins and history of development. ${ }^{26}$ This act of erasure takes place through what I describe as ethnic classism (or in the present case, Levantine classism). I use this term to emphasize how representations of race and class intersect, with the discourse of race concealing an underlying discourse of class, or vice versa. As Ann McClintock argues, the conflation of racial and class markers originated with the 19th-century scientific discursive turn in which "the rhetoric of race was used to invent distinctions between 
what we could now call classes." ${ }^{27}$ Examining the history of the British Empire, McClintock sheds light on a social paradigm that justifies the control of marginalized groups by means of the civilizing mission. This imperialist model draws on the metaphor of the household, consisting of an imagined universal "family of man" in which the British middle class presides over a hierarchized list of minorities and subgroups distinguished by race and class. Most often, the difference between subgroups from the metropole and colonial subjects is expressed through an ambiguous representation where racial distinctions are evoked to express class difference. In this process, the "domestic space became racialized and colonial space became domesticated." McClintock coined the term "commodity racism" to explain in particular the role of consumption and the "cult of domesticity" in shaping the representation of race and class in the British Empire. ${ }^{28}$ Here, I use the phrase "ethnic classism" to refer to the active consolidation of class status through the manipulation of racial representation. I seek to explore this dynamic in relation to broader economic and social factors beyond consumerism, stressing in particular the role of the working class and its representation in the construction of a cosmopolitan and elitist image. Moreover, I seek to move beyond the binary scope of metropole and colony in order to account for the interplay of several imperial and cultural spheres of influence as well as for the conscious role of individuals in this process.

Ethnic classism constructs an imagined universal hierarchy of race and class, with European bourgeoisie, whiteness, and cosmopolitanism at the high end of the social and ethnic ladder and working-class colonial subjects at the bottom. ${ }^{29}$ Through the racialization of labor, members of the working class are reduced to Orientalized characters or faceless locals expunged from a Eurocentric bourgeois portrait. Moreover, social ascension and descent precipitate modifications to racial representation: those in the ascent are depicted as being physically and morally close to the European white bourgeoisie, while those in the descent are presented in exaggerated and racialized ethnic caricature.

Ethnic classism is a manifold act, a covert shift along the binary of race and class that, occurring simultaneously in both colony and metropole, affirms European bourgeois domination. On the one hand, it proletarizes colonial subjects, rendering them part of a monolithic group regardless of their background; on the other hand, it racializes the metropolitan labor force by conflating its image with that of colonial subjects. This dual process ignites the imperial fantasy/nightmare of control over the metropole and the margins that is articulated through the civilizing mission, which promises social ascension and economic advancement to both groups. These groups' integration of European bourgeois culture is represented as a form of racial evolution. ${ }^{30}$

\section{LEVANTINE SUBJECTS BETWEEN EMPIRES AND CIVILIZING} MISSIONS

In order to explain the dynamics of ethnic classism in Jacob's Ladder, it is first necessary to describe the intricate colonial map in which Levantine subjects were embedded. The novel invites us to look beyond what Ann Stoler and Carole McGranahan have called the "tunnel vision" of postcolonial studies, or the focus on a unilateral relationship between metropole and colony or colonial past and postcolonial present, and toward a matrix of imperial, colonial, and social relations. ${ }^{31}$ Specifically, it reveals a range of intraimperial, intracolonial, and even intracommunal networks that shaped Levantinism. ${ }^{32}$ Moreover, 
the novel documents what it means to be between empires, or the subject of multiple empires at once, to belong to many cultures and nation-states, and how competing imperial projects shape the everyday practices of different communities and social strata. In referring to imperial projects rather than empire, I have in mind Ann Stoler and Carole McGranahan's concept of "imperial formation," which attends to the interaction of several imperial ideologies that shape colonial life and precipitate various modes of adaptation and resistance. As the authors posit:

We take up the notion of imperial formation as a critical analytic to underscore not the investable rise and fall of empires, but the active and contingent process of their making and unmaking. Our interest lies less in institutions and fixed ideologies than in the prevalence of blurred genres of rule and partial sovereignties. Empires may be "things," but imperial formations are not. Imperial formations are polities of dislocation, processes of dispersion, appropriation, and displacement. They are dependent on moving categories and populations. Not least, they are dependent on material and discursive postponements and deferrals: "the civilizing mission," imperial guardianship, and manifest destiny are all promissory notes of transformation. ${ }^{33}$

Intricately divided among numerous spheres of influence-including the Arab and Muslim world, the Ottoman, French, Italian, and British Empires, and emerging Arab nations-the colonial Middle East calls for analysis that accounts for this broad matrix of relations, movements, and dislocations that have shaped each other and continue to shape the region. As Stoler indicates, empires were malleable and permeable entities that often borrowed strategies of control from each other. Consider, for instance, the situation of colonial Egypt, a semiautonomous nation under British occupation that itself ruled over Sudan, pledged allegiance to the Ottoman Porte, and was heavily influenced by French culture due to the Suez Canal project and educational missions that catered to elites and minorities. Among these missions was the Alliance Israelite Française, a French education initiative whose aim was to assimilate Jews in the Mediterranean basin to French culture. ${ }^{34}$

The demography of colonial Egypt reveals how colonial subjects navigated these overlapping political and cultural currents. In her history of Egyptian Jews, Gudrun Krämer reveals the wide gap between official records of migrants' nationalities and their culture of origins: "A large percentage of those listed as French, British, or Italian subjects or protégés had not actually come from Great Britain, France, or Italy, but from areas controlled and occupied by these powers ... or [by the former] Ottoman Empire." 35 By living in a "neighbor empire" rather than their own, many colonial subjects were able to accrue privileges that they would not have acquired had they remained subjects of only one empire. Traced on the map, the trajectory of migrants from Tunisia, Greece, or Turkey to Alexandria appears as a short, straight line, but the complex legal system to which they were subjected was the product of a convoluted web of diplomatic protocols and agreements decided on by many imperial centers-Paris, London, Istanbul, and Cairo-with the intention of defining their status in the host empire. The stark contrast between the migrants' point of departure and arrival, and the corresponding diplomatic meandering among metropoles, opened a liminal space for some colonial subjects to secure a better social or economic position. As Ann Stoler and Frederick Cooper posit:

Social taxonomies allowed for specific forms of violence at specific times. How a person was labeled could determine that a certain category of persons could be killed or raped with impunity, 
but not others. It could open or close down the possibilities for marriage, housing, education, or pensions. At the same time, the criteria used to determine who belonged where underscored the permeability of boundaries. ${ }^{36}$

Kahanoff's novel shows how this dynamic was pertinent not only to imperial powers, but also to colonial subjects, who similarly exchanged knowledge and strategies across imperial borders. The novel depicts atypical situations, such as the colonized, Orientalized subject becoming the master or the European colonizer the servant, that invite us to reconsider dynamics of class and race in colonial relations.

\section{BETWEEN CULTURE CAPITALS}

Written before the Egyptian revolution of 1952, and before the dislocation of various ethnic groups that made up Levantine society, Jacob's Ladder represents a rare moment in the history of Levantinism in Egypt. Unlike early turn-of-the-century narratives such as Lawrence Durell's The Alexandria Quartet, which present Levantine culture as a decaying form of European cosmopolitanism giving way to Arab culture, or even post1960s narratives such as Jacqueline Kahanoff's own writings, which depict Levantinism as part of a bygone past, Jacob's Ladder looks nostalgically at an Arab heritage that was lost to French and British cultural influence, while attempting to come to terms with Levantine cosmopolitanism as a culture in the making. Kahanoff adeptly captures a society in transitioning toward new forms of cultural capital. Conveying this point, the opening scene describes an idyllic setting in the house of the family patriarch, Jacob Gaon, a revered Jewish merchant from Iraq who lives in harmony with his "traditional" Arab milieu:

Horses' hooves clattered through the silence of the narrow lanes, and Jacob Gaon made ready to receive his sons. He pictured them in their European suits, coming from their modern homes to the timelessness of this lane, with its houses withdrawn behind high walls, flowering with Jasmin [sic] and Honeysuckle, its echoes of grave voices exchanging the Arab greeting: "Peace be upon you"; in it no women walked unless she were draped in her habbara. The old man heard the carriage pull to a stop, heard steps on the path, and the hushed whispers of his sons while they waited for the servant to answer their knock. He detected the urgent note in their tone. . . But Jacob soon drove worry from his fine old face, and composed it into lines of majestic serenity. Whatever his doubts, his sons must always see him stern and detached, the Patriarch. ${ }^{37}$

Lamenting alienation from an earlier state of things, or a "fall" into a European way of life that distances the younger generation from this old, serene, paradisiacal quarter, the text creates a spatial-temporal rupture between Jacob's vanishing world and the world of his sons, who uphold a European lifestyle. Jacob Gaon lives in a reclusive house that blends perfectly with its geographical and cultural location. The residents in his area speak Arabic, and men and women live according to age-old religious customs. The clattering of the horses' hooves, described at the beginning of the quotation, announces the disturbance of this milieu by the arrival of Jacob's sons, who are introduced as houseguests, emphasizing their outsider status in that harmonious world. Whereas the sons talk about expanding their business, Jacob uses biblical quotes and aphorisms to advise them to preserve tradition and their relationship to previous clients. Solidifying this divide between father and sons, the scene arranges the characters in an ethnic-classist 
pattern with the traditional Arab men, Jacob, and the servant Ahmed on one side, and Jacob's Europeanized modern sons on the other: "Ahmed . . . a tall and severe man, came in with Turkish coffee. He had been with Jacob since the day of his arrival in Egypt, and had come to look like him, except that he was younger, and wore finer galabiehs." 38 Standing silently in the shadow of Jacob Gaon, Ahmed appears to be Jacob's alter ego, a reminder of his humble beginnings. This conflation of the image of the patriarch with that of his servant is a classic Orientalist gesture, calling to mind Edward Said's discussion of Orientalist representations of Arabs and Jews that collapse all distinctions between them. ${ }^{39}$ Whereas the scene lumps Jacob and Ahmed into a single racial category, it is attentive to the clearly marked symbols of European bourgeois class associated with the sons, such as the suits, their use of English, and the their modern European residence. By focusing primarily on race in the former instance, and invoking race and class (e.g., "English" and "European") in the latter instance, the scene constructs an ethnic-classist divide that associates class ascension with white bourgeois economic and cultural capital, and "traditional" non-Europeanized subjects of any class with an ambiguous racial label.

Although the narrative conflates Ahmed with Jacob, it still records his vital and subtle social role, which even Jacob Gaon could not perform:

In this part of Cairo, where Moslem and Jew sent servants bearing gifts to his neighbor on religious holidays, where everyone lived by the peace handed down to him by his forbears [sic], obeyed an ancient order and accepted the fortunes and the misfortunes of life as the will of God, women still lived in the seclusion of their own quarter. ${ }^{40}$

The text suggests that the serenity of the neighborhood depends on the mediation of domestic helpers who act as liaisons between Muslim and Jewish neighbors. As Stoler has pointed out, "servants policed the borders of the private, mediated between the 'street' and the home, and occupied the inner recesses of bourgeois life; they were, in short, the subaltern gatekeepers of gender, class and racial distinctions that by their very presence they transgressed." ${ }^{11}$ The servants' mobility contrasts with the tranquility of the age-old quarter. Unlike their patrons, they can cross social, spatial, and cultural boundaries and bridge distances between groups. Consequently, the stability of the Gaons depends on these subtle connections established and maintained by the servants who act on their behalf.

The connections between visible class markers and invisible class relations that organize Levantine culture become clearer as the novel turns to Smadja Brothers, the Parisian-style department store in central Cairo owned by Rachel's Tunisian grandparents. In the second chapter, the reader encounters Nathan Smadja for the first time as he stands in front of his store, dwarfed by its large entranceway. In contrast to Jacob and his sons who belong to two distinctly divided worlds, Nathan Smadja upholds a Levantine lifestyle that brings together tradition and modernity, East and West. With his paunch, his gold watch, and his crooked thumb, he also embodies a stereotypical racialized Mizrahi look. As the narrative proceeds, he begins to chat with customers and shout at peddlers. To communicate with his diverse clients and with peddlers, he uses a mix of languages: French, Arabic, and perhaps some Italian. His linguistic register is that of the everyday, a colloquial idiom delivered in a theatrical manner that, marked by short sentences and interjections, is reminiscent of the suq, the traditional marketplace, or of advertisements: "Don't worry, we have everything you need, and at a good price 
too. . . . Madame Biagiotti! . . Come I'll show you the new lace we're unpacking-a dream! Extraordinary! The finest! Just arrived from France for your trousseau!"42 Although Nathan Smadja associates his store with luxurious French material culture, his behavior as a manager is not consistent with the elite European image that he seeks to portray. ${ }^{43} \mathrm{He}$ occupies an awkward position between a department store manager and a street peddler promoting his merchandise, though he feels most comfortable standing by the entryway shouting and competing with street vendors and beggars:

He shouted at the small beggars, glued to the display windows by their running noses and sticky fingers, "What! Soiling our windows! Let me catch you at it again, and I'll beat you to death!" . . A young pedlar came up boldly, the basket strapped around his neck full of threads, needles, elastics, buttons. "For your daughters, sir?" He asked impudently. Nathan laughed. "You can try to undersell me, you rogue, but don't expect me to undersell myself. Off with you!"44

The scene reveals the fragility of the class distinction between Nathan and the young street peddlers surrounding his store, especially given that he does not fit perfectly into the refined middle-class Francophile image. The young street peddlers reflect Nathan's childhood: as the narrator stresses, the Smadja brothers started off as "two small ragged pedlars in the streets of Tunis." 45 The marks left by the beggars' hands and noses on Nathan's modern vitrine destroy the illusion of the seemingly invisible glass pane connecting inside and outside. They render this pane an implicit stop sign, a solid barrier that prevents the poor and the unwanted more generally from entering. Simultaneously, the marks evoke the traces of Nathan's past as a young street vendor and of his and his family's social ascension. Just like the street sellers, Nathan once stood on the margins of his society, but now he belongs to a liminal space between inclusion and exclusion. Standing in the doorway, he straddles the working- and middle-class, and the Arab and European, worlds.

Whereas the previous passage reveals the class dynamics in the liminal space between the store and the street, the following scene, in which Nathan takes his granddaughter to the workshop, or atelier, located at the back end of the store, reveals another social stratum of Levantine society:

The big sunny room exploded with laughter, the gay whirr and purr of the sewing machines.... That the girls were pale, smelling of sweat, cheap perfume and bad breath was something Rachel did not notice when Nathan opened the door and a great shout greeted her, "Here is Mascotte to bring us luck!" The girls cleared a space on the long table, and hoisted up the child, to sit enthroned among the fabrics, the ribbons, the flowers, the cushions bristling with pins and needles, and the light spools of thread. Even Madame Marthe, the stern première, who had been with the Smadjas since Tunis days, relented in her discipline, and let the girls drape Rachel in rolls of fabric, which trailed regally behind her as she paraded up and down the table, stumbling over obstacles, dragging her doll after her. They laughed and clapped their hands, exclaiming, "Will we be bridesmaids at your wedding, Mascotte?" ${ }^{46}$

If Smadja Brothers serves a cosmopolitan Levantine crowd, the atelier depends on a large group of Levantine employees, the workforce that recreates Parisian fashion for the store's clientele. For Rachel, Smadja Brothers materializes as both a department store and a household. The atelier, full of laughter, seems to her like a fairytale space whose employees are part of the extended Smadja family. The scattered French references that she hears_-"mascotte," "première," "Madame Marthe"-hint at a dominant 
Francophone culture among the workers and recall the initial conversation between Nathan Smadja and his Italian client Ms. Biagiotti. Yet, while the portion of the description that conveys Rachel's perspective is upbeat and positive, the rest of it focuses on grim traces of manual labor and class distinction: "the pale" workers, "the smell of sweat," the "cheap perfume," and the "stern" look of the première.

The image of young Rachel draped in fabric and pretending to be a bride foreshadows a scene later in the novel in which the family celebrates the wedding of Rachel's aunt. This significant social event demanded the labor of the atelier workers, who were in charge of making the family's outfits, but apparently did not demand their attendance. In contrast to the atelier, the wedding space, elegant and refined, is free of all traces of labor:

Something had happened in this society, which made money the yardstick of all values. This was a liberated society, acquisitive, competitive, but also fluid, and doubtful of itself. Old values were breaking down, and there was a lack of new ones to fill the empty space. Money was there, as a common language between the once segregated communities, money was the symbol of power, esteem, love given and received, money was the measure of things. Yet people who made such remarks felt a vague shame in doing so, while longing to feel again what they had felt in the synagogue. ${ }^{47}$

In this passage, the narrator describes the formation of an ambitious and self-doubting class that depends on material wealth to consolidate its status. In this highly fragmented elite Levantine world that has lost contact with its roots, money rather than cultural capital is the shared common denominator. Material acquisitions, particularly European goods imported by the department store and the fashion produced in the atelier, are what indicate one's newfound social position in a socially and economically shifting world.

Rachel's family members, however, are neither working class nor established colonial elites. Midway on the social ladder, they must work hard to secure their social status in the emerging cosmopolitan community. Interestingly, the Gaons and the Smadjas find themselves in a paradoxical position, both constricting and strategic, in relation to the society of which they wish to be a part. Being constantly under public scrutiny as promoters of the latest trends and fashion, their command of European material culture is crucial to both their social appearance and their financial progress. The family members, then, are themselves objects of display both inside and outside the department store. Due to their dependence on commerce, they are forced, in a sense, to model European material culture for others and spearhead the social and cultural transformation of the city regardless of its impact on their lives. Yet, by taking on that role, they also invent themselves as colonial elites. For instance, Rachel's position as the daughter of department store owners and merchants prescribes her social and gender image. ${ }^{48}$ She only obtains permission to wear lipstick because of "the part [that] the sales of lipstick had played in promoting the Gaons' prosperity." 49 As the seamstresses describe her, Rachel is the "mascotte," or the visible and marketable emblem of bourgeois Levantinism, created in the department store's atelier.

To expose the gap between the actual Levantine lives of the Smadja family and the seamless elite European life to which they aspire, the novel turns from the public sphere of the department store to the domestic space of the Smadjas' house. Describing Nathan Smadja's "Grand Salon," the narrator depicts the family's comic and gauche attempts to 
adopt a European bourgeois lifestyle. Despite the European decoration, the family home still features as a predominately Tunisian space:

[Nathan] looked with pleasure at his table, opened at full length to seat nearly twenty people, adorned with the best tablecloth with two big soup tureens . . . overflowing with couscous. . . . He walked around the table, and bumped into a sculptured bronze corner of the sideboard, but its style, which Nathan proudly though inexactly called "Louis XV" was worth all the bruises it inflicted on the family ... Sandra, a chubby girl of twelve, with blue eyes and black hair . . . saw him throw the stone into one of the Chinese vases on the sideboard. Everything went into those vases except flowers, she thought. When she married and had her own house, she would not allow people to do such things, nor to yell from one room to another. Throwing herself on her bed, she began to read a French novel, longing for the elegant world it described. ${ }^{50}$

The bruises inflicted by the new furniture on the Smadjas' bodies highlight the oftenundocumented efforts and pains involved in becoming bourgeois. The large table laden with couscous, the shiny golden furniture, the mistakenly identified "Louis XV" sideboard, and the misused Chinese vase mark the contrast between idealism and praxis of culture. Rejecting the dissonance between her family's lifestyle and French culture, Sandra, Rachel's aunt, escapes her immediate surroundings into an imaginary European world that she creates from fictional literature.

CONTROLLING THE "FAILED" CIVILIZING MISSION: COLONIZED

MASTERS/COLONIZING SERVANT

Thus, despite their ambitious aspirations, the Smadjas ultimately inhabit a culture that is neither European nor Near Eastern. Alice Gaon, Nathan Smadja's daughter, grows conscious of her family's midway position on the social ladder, despite its accumulation of European cultural and economic capital. She attempts to improve her family's lot by seeking the expertise of a domestic helper who will educate her daughter Rachel and help her to gain colonial elite status. While on a trip to London, she hires Miss O'Brien, a British nanny, but not before the following debate between her and her husband, David Gaon, takes place:

"But why not an Italian nursemaid?" David suggested. "It's an English woman, criticizing, looking down on us, drawing the child away, I don't care for ... " he said lamely ...

Alice argued heatedly. "The children who have English nurses won't play with those who don't, and the English nurses won't even talk to Italian nursemaids. They aren't admitted to the same playgrounds either. It just isn't fair to the Child. We must think of her future and give her the best advantages." ${ }^{11}$

Alice's words provide insight into the fine lines of a colonial legal system that hinges on the control of minorities. At first glance, the protégés of the British Empire seem to enjoy a distinct social and legal status within Egypt that contrasts with that of "natives." The scene, however, exposes a far more nuanced hierarchical taxonomy, one accounting for culture of origin and social class. Just like local subjects, minorities, including white Europeans from other empires, are subject to a classificatory regime that regulates their privileges, including their spatial and social movement. In order to secure their social position, the Gaons have to navigate this intricate colonial web woven by class and race. 
Alice's remarks also reveal how ethnic classism plays a central role in shaping the status of the colonial elite and how being European breaks into several categories wherein the national and ethnic background of the nanny-Italian and British, respectivelysilently marks the difference between groups and helps those from the same stratum to bond. The mere presence of an English nurse has the potential to change Rachel's status, for this nurse would give her access to certain public places designated for English citizens. In this context, the different colonial sites, such as the segregated spaces in Ezbekieh Gardens, serve as a microcosm for the colony, or rather an incubator in which the colonizer shapes the habitus of the different minorities and consolidates them into distinct social groups and races. Like the glass barriers in the department store that kept out the unwanted beggars and peddlers, colonial Cairo subtly divided the elite Levantine community and controlled its mobility.

By hiring a British nursemaid, Alice Gaon overcomes the spatial and social restrictions in colonial Cairo and takes control of her children's education, ensuring that the colonial civilizing mission reaches its presumed goal of transforming her children into Europeans. In Distinction, Pierre Bourdieu likens the effortless circulation of established notions of taste and distinction in bourgeois milieus to the casual transmission of a family "heirloom" from one generation to the next. ${ }^{52}$ Following Bourdieu's logic, the nursemaid would substitute for the parents and transmit a ghostly English bourgeois "heirloom" that distinguishes Rachel from the rest of her society.

A rich colonial subject, Rachel's mother uses the resources available to her to turn the colonial model upside down and fulfill her social ambitions. Alice occupies two positions at once: one of quasi powerlessness, as she decides to transfer part of her agency as a mother to the nursemaid, and one of control, as she becomes the employer of her colonizer and thus takes charge of the colonial civilizing mission. David's objection to Alice's choice exposes the colonial anxiety involved in hiring an English nanny, who will only serve as a reminder of the dichotomy between colonizer and colonized, Western and Oriental, within the household. The paradoxical effort to hire an English nanny to reach the aspired objective of the civilizing mission recalls Stoler and Cooper's analysis of the tension between discipline and desire in colonial relations: "The ambiguous lines that divided engagement from appropriation, deflection from denial, and desire from discipline not only confounded the colonial encounter, it [ $\mathrm{sic}$ ] positioned the contestation over the very categories of ruler and ruled at the heart of colonial politics." ${ }^{3}$ Positioned inside the house, the English nursemaid represents, in Edward Said's terms, the colonial agent that places the colonized Orientals under her constant gaze and marks their "need" for "corrective study," creating a traumatic split in consciousness. ${ }^{54}$ As a self-imposed, financially rewarded, panoptic eye that operates by "distributing individuals, fixing them in space, classifying them . . . training their bodies, coding their behavior [and] maintaining them in perfect visibility," she embodies the quintessential Foucaultian nightmare. ${ }^{55}$ The position of the British nanny contrasts with that of Amina, Daniel Gaon's Syrian wet nurse, whose low place on the social ladder permits the Gaons to adopt a colonial bourgeois attitude. When Amina breastfeeds Daniel for the first time, her body is placed under the scrutiny of Rachel's family, exposed, disinfected, and subjected to an intraclass colonial gesture of appropriation. ${ }^{56}$

Internalizing colonial values and language through the help of her nursemaid, Rachel stands out as the modern European civilized subject amid both the "natives" and the rest 
of the Levantine community. The central role of the nanny becomes more evident when Moses, Rachel's uncle, affirms that a nanny is a significant investment, since she can help Rachel marry into the "best families." By inculcating colonial and gender performance, the nanny turns Rachel into profitable economic capital for the family, and thus helps to consolidate the family's social and financial situation in Egypt. The story takes an ironic turn, however, when Rachel's parents realize that Miss O'Brien, the nanny whom they hired, is actually Irish, and that her connection to English culture is thus colonial in nature:

"I thought English nurses were so fussy, so hard to please," [Alice] couldn't help saying.

"I am Irish, Mrs. Gaon," the nurse said stiffening.

"Oh no," Alice protested, wanting nothing but the best. "You and your parents are born in England and ..."

"Miss O'Brien speaks English, so Irish or English, what's the difference," David [Gaon] interrupted her, conciliatory.

The nurse flushed. 'I am Irish. The eagle and the dove both fly, but that doesn't make them the same kind of bird." 57

As the Gaons' social circle expands, Alice's ambition for social ascension propels her to hire a Sudanese servant with experience working in English houses, whose task it is to help the household achieve an aspired English image:

Hassan, now secure in his position, introduced into this most un-English household all he had previously learned, with an enthusiasm, which might have been his way of catching up with years of restraint. He washed fruit in permanganate-tinted water, and had Anna sew squares of fine net, trimmed with green wooden beads, to cover the children's food and drink. They were copies of those bought by British officers at the supply centers in their camps, and came to replace Miss O'Brien's more casual cheese-cloth.

"He's far more meticulous than nanny," Alice remarked. ${ }^{58}$

Hassan, who occupies an inferior position on the colonial ladder, possesses the expertise that can perfect the colonial simulacrum. The family's contact with English society remains limited to social events, a situation that hinders their mastery of English etiquette. The presence of Hassan is crucial to the construction of the fantasy of the European bourgeoisie and its racial and class hierarchies. It is through the contribution of a Sudanese man and an Irish woman that the Gaons can move up the social ladder and, by extension, modify their image from faceless Orientals to bourgeois Europeans. Ironically, in their effort to create themselves as model colonial subjects, the Gaons also define and reaffirm what it is to be British middle class by following Hassan's exaggerated practice of English etiquette.

\section{THE OTHER LEVANTINES}

The presence of the British nanny heralds the end of Rachel's Levantine multicultural world, consigning her to a monolingual culture. As the narrator describes it: 
She didn't go to see Nonino and the girls in his store.... She didn't speak Arabic, Italian, or even French any more, but only English, even with Papa and Mamma. . . O Only sometimes on Nanny's day off, when she was left with her mother, she became again Caline, who spoke French. ${ }^{59}$

As she gains access to more and more places in colonial Cairo designated for British citizens, Rachel is taught to copy the British middle class. Miss O'Brien and later another English governess, Miss Nutting, become Alice Gaon's European alter egos, chaperoning Rachel as she navigates the colonial sites of Cairo. Walking in a white panama hat and a blue muslin veil with her nanny, Rachel internalizes British colonial consciousness, which constructs her as inferior and different. It is then that she suddenly identifies with a beggar:

She caught sight of a band of beggars hardly older than herself, their bodies showing through torn rags, besieging passers-by, fighting among themselves in their hunt for cigarette butts, scattering quickly when a shawish [police officer] descended upon them with a stick ... except for one who never ran away ... he stopped to see her go by, and smiled at her just as she smiled at him, a little bit only, from the corner of the eye. But now, with the blue veil, she could not even do that ... the little beggar was more handsome than her cousins Henry and Claud, with his flashing white teeth and black eyes, and far braver ... She didn't want him to be locked up, because he was brown, as she was, and they were together against shawishes and pink people who spoke English. ${ }^{60}$

Strolling the streets of Cairo, Rachel begins to see the city and herself through a blue veil, which evokes the blue eyes of the colonizer, and adopts colonial binaries and hierarchies. Her realization recalls Franz Fanon's Black Skin, White Masks, in which he describes the psychological divide within the colonized subject who perceives herself through the European Other. ${ }^{61}$ The passage most likely alludes to W. E. B. Dubois's renowned description of "double consciousness," or the alienation experienced by an individual of color who internalizes the dominant racist view of herself and begins to watch the world from the perspective of the marginalized, as if through "a vast veil." 62 When Rachel, donning an English lens, recognizes herself in the image of a poor "brown" beggar, she also adopts an ethnic-classist perspective that equates bourgeois with European and white, and native and local with other races and poverty. Following this logic, Egyptian identity becomes incongruous with material wealth, European education, and multiculturalism, since from a Eurocentric perspective to be an "authentic" native is tantamount to being poor and Oriental.

Ironically, in adopting the colonial racial binaries white/Other, Rachel does not recognize that what she considers English also divides into many categories and that her Irish nanny, as a subject of the British civilizing mission herself, might share a similar experience within the British imperial paradigm. ${ }^{63}$ Instead, Rachel perceives being British as a singular category, that is, white Anglophone. Rachel's misrecognition of the distinction between English and Irish subtly highlights the difference between the visible and the invisible, between the performance, or the labeling, of a culture and the hidden class and ethnic distinctions that actually exist within the group embodying that culture.

Although Rachel internalizes British colonial racial categories, her previous experiences allow her to see a third perspective, invisible to the Eurocentric ethnic-classist lens that divides the population into native "lower-class Arabs" and "Europeans" or those who are European-like. Unlike Miss O'Brien, Rachel can clearly read the fine 
distinctions that make up the social web of Levantine colonial culture. Her awareness of these cultural landscapes becomes clear in one scene when she introduces Miss O'Brien to Egypt's Levantine commercial class:

"How do you know he's Syrian [a shopkeeper]," Miss O'Brien asked puzzled. Except for the lower-class Arabs, she could not tell people apart, and it had intrigued her not only that Rachel knew these things, but that there were so many shades of familiarity, respect, condescension, in her manner of saluting people in the street; more than once, when in her own unavoidable dealings with natives, servants and such, Rachel had acted as interpreter, she had instinctively modelled her conduct upon the child's. ${ }^{64}$

In contrast to the earlier Orientalist description of Jacob Gaon and his servant Ahmed, this paragraph hints at the minute nuances of class structure in modern Cairo. Whereas in the earlier description the traditional class markers are blurred, here the novel draws attention to the emerging Levantine cosmopolitan society with its wide range of European and Near Eastern traits. Yet the scene is not free from colonial bias. Occupying an ambiguous position between native informant and colonized subject, Rachel risks reiterating the different racial categories defined earlier by the colonizer.

Rachel's self-recognition as "brown" precedes a sequence of events in the novel that exposes the racial and class anxiety of a Levantine culture that has adopted the European bourgeoisie as its model. When Miss O'Brien comes to understand the makeup of Egyptian society, she helps Rachel to reconnect with the multicultural domestic helpers who make up the other Levantine world found in the Gaon household, despite the disapproval of Rachel's mother:

"Where's Rachel?" "I sent her to the kitchen on an errand, Mrs. Gaon." Alice frowned. "You could ring for Mahmoud to come." "I know, but she so enjoys looking about in the kitchen. And it would be a pity if she forgot Arabic and Italian. It's so lovely that she can speak them! Those are the people she's always known and will always live with, and I think she misses them." Alice's frown deepened, and she sounded displeased. "I want Rachel to speak English without a trace of an Egyptian accent, without Arabic words creeping in."

Seeing Rachel enjoying more freedom, Alice Gaon attempts to emulate the rigid colonial spatial control of the Ezbekieh Gardens in her own household by instructing Miss O'Brien to use the bell to communicate with the domestic help rather than send Rachel. Alice's anxious tone alerts the reader that Levantine culture, unlike its elitist reputation, exists in contexts beyond the grasp of the upper classes. Specifically, the bell serves to situate the other Levantines into the background by marking their status under the undifferentiated category of labor, erasing their diverse backgrounds, languages, and cultures.

The novel further emphasizes the racial and class, or ethnic-classist, anxiety within Levantinism when Alice's father, Nathan Smadja, defends his daughter's social ambition by referring to hărat al-yahüd, or the Jewish quarter, as a dreaded Oriental space: "Did we give our girls a good schooling for them to live like Hara Jews?"66 For Alice's family, Jews from the hăra represent a lower position on the colonial social ladder relative to the Gaons and the Smadjas: they are closer to faceless "natives" than to the elite Levantines. Unlike the British-style neighborhood of Garden City where Alice resides, or even the traditional affluent Arab neighborhood of Abbasieh where Jacob Gaon lives, the hāra 
embodies the fantasmatic threat of becoming working class and, by association, Arab again. ${ }^{67}$ Use of the Arabic word hăra, transliterated in English characters in the text, exposes the tension within the bourgeois colonial dream-European on the surface but haunted by its Arab Other. At one point in the text, Alice remembers in disgust the Jewish women from härat al-yahūd whom she met while searching for a wet nurse for her son: "Alice shuddered recalling those who have come to be interviewed, gaunt, haggard women, their eyes blurred by ophthalmia."68 For Alice, hārat al-yahüd is a reminder of Nathan Smadja's beginning as a poor peddler, a native, and a workingclass Oriental expunged from the colonial social map and the Eurocentric perspective of history that push the native colonized into the background. Unlike the monolithic Orientalist image suggested by the novel, $h \bar{a}$ rat al-yahūd harbored a diverse community comprised of individuals from a range of social, cultural, and religious backgrounds, including Egyptian Muslims as well as Mizrahi and Ashkenazi Jews. ${ }^{69}$

The racial and class anxiety reaches its height when Alice Gaon discovers that Donia, the Lebanese Christian maid, converts to Islam, elopes with Hassan, the Sudanese servant, and forces her daughter, Angèle, to quit her French school. ${ }^{70}$ Alice Gaon's shock exposes how Angèle represents the bourgeois anxiety of the dreaded outcome of Levantinism, a fate that could have been shared by her own daughter. Here, Angèle, "who was practically brought up" with Rachel and began her life as a Levantine Francophone girl, serves as Rachel's alter ego. Whereas Angèle moves closer to dismissed African, Arab, and Muslim cultures, hence down the colonial ethnic-social ladder, Rachel follows the opposite trajectory, closer to the British middle-class model. Unconsciously adopting a colonial role, the Gaons search relentlessly for Angèle in order to return her to her French school. $^{71}$

\section{A LEVANTINE ORDER OF THINGS}

In the third part of the book, titled "The Invader," Rachel's mother hires an "authentic" English governess, Miss Nutting, to guarantee that her daughter is properly civilized. Miss Nutting imposes more restrictions on Rachel and heightens her sense of inferiority, causing Rachel to resist as she attempts to understand her position as a Jewish woman in Egypt. During one of her confrontations with Miss Nutting, Rachel sees some "street rioters" and joins them in chanting "Egypt for the Egyptians." She finally slaps the nanny on her face and forces her to quit. ${ }^{72}$ By using the word "invader" to refer to the arrival of the new nanny, and by synchronizing Rachel's confrontation with her with a public condemnation of the British occupation, the text clearly parallels Rachel's action with the Egyptian nationalist project. ${ }^{73}$ On the surface, the scene reads as a rebellious gesture made by a colonial subject seeking to reclaim a national identity. But by identifying momentarily as Egyptian, Rachel actually seeks to resolve a colonial dilemma-the mutual exclusivity of European modernity and national belonging to Egypt. In addition she attempts to come to terms with the "effendification" of Egyptian culture, described by Miccoli as "the social and historical process leading to the creation of a new national middle class, whose identity was rooted in the figure of the Egyptian peasants, 'repositories of eternal truths.",74 The ethnic-classist representation divides the population into Europeans and Levantine subjects on the one hand, and Orientalized natives on the other hand. For Rachel, this binary casts Egyptians who possess European 
cultural capital as outsiders, as evidenced in the passage described earlier where she encounters the beggar with Miss O'Brien.

When Rachel succeeds in resisting her British nanny's orders and prejudices against Arab cultures, she begins to distance herself from English and French colonial perspectives and to embrace her Arab heritage. ${ }^{75}$ She finally makes the distinction between her ancestors, the "Gaons," and the "Gauls," the founding ancestors of France, about whom she learned in her French school. ${ }^{76}$ After this moment of self-recognition, her grandparents" "French" department store transforms before her eyes into an Oriental space onto which she projects her new self-perception:

Back in Cairo, if ever she went to Smadja Brothers, a run-down store with the air of a bazaar, she wondered how, in the old days, marching down the creaking aisles with her grandfather, she had believed this was the grandest place on earth. Well she thought disdainfully, she had grown up now, and lost all her silly illusions." 77

Unlike the cosmopolitan department store, the bazaar is endowed with a geographical and cultural origin and connects to a local imaginary and history. Similarly, Rachel realizes that she herself is an "Oriental" woman with a unique heritage. Rachel's recognition of the double nature of the Levantine world, its combining of East and West, still betrays her ambivalence: her view of the store as a "rundown bazaar" indicates disappointment in her recent self-discovery. Her perception is still filtered through a colonial lens, depicting the East as inferior and Levantinism as a fake imitation of European culture rather than a unique culture of its own.

Such an Orientalized depiction of the store, which restores it to its Near Eastern context, is accompanied by a parallel realization and reordering of domestic space. Kahanoff concludes her novel in Rachel's house with the Gaons and the Smadjas celebrating Passover. Alice, Rachel's mother, struggles to set the table in the proper way for such an event. Only Ahmed, who serves Jacob Gaon, knows the fine details of this ceremony. Rachel rebukes him for not cooperating with her mother and showing her how to set the Passover table. Ahmed finally agrees to help: "Rachel assisted Ahmed in preparing all the things necessary for the prayer, and setting them as they should be. Thus she learned from the old Muslim all that she as a Jewish woman needed to know.",78

The Hebrew verb le-seder, which is related to the noun "seder" and means "to arrange" or "to put in order," provides insight into the broader meaning of this scene. ${ }^{79}$ Setting the seder table stands for rearranging the order of things. By concluding with a ceremony that unites the Gaons, the Smadjas, and the domestics, Kahanoff rewrites the history of Jews in Egypt according to her own perspective and narrative temporal sequence. The Gaons' seder table allows a space for contradictions and differences, including the irony of celebrating Passover, a holiday that commemorates the Exodus, in Egypt. The story even takes an anti-Zionist turn when Jacob Gaon, the patriarch who has traveled to Jerusalem to spend the remainder of his days, decides to return to Cairo after being appalled by the city. ${ }^{80}$ Rachel's family members now live under a "Levantine" order of things, one in which cultures are mixed without reference to origins or authenticity: Rachel's English education was transmitted by a British nanny, and the table for the seder was set by a Muslim servant. 


\section{CONCLUSION}

While the novel celebrates Egypt's Levantine culture as a unique model of cosmopolitanism, it also exposes the invisible steps of the Levantine social ladder by bringing to the forefront the various racial and class taxonomies that subtly govern social relations and class ascension. Rachel Gaon's Levantine world represents the intersection of many histories and cultures, beyond the reductive lens of European cosmopolitanism. At many points, the novel reveals how colonial categories and relations change quickly and dynamically amid the interplay between empires and their subjects. Even Levantinism, that East-West amalgam, surfaces as a game of doubles that divides the world into bourgeoisie and working class. Chasing the colonial promise of social ascension and financial progress, the Gaons and the Smadjas catch their own reflections in many parts of the city and in the image of servants, nannies, and beggars. Ahmed, Miss O'Brien, Miss Nutting, Donia, and Angèle embody some of the social and class anxieties inherent in Levantine culture, whether an erased history, a future aspiration, or a feared outcome that does not fit a European bourgeois image. The text demonstrates the fragility and malleability of racial and class categories: markers of distinction adopted by the Levantine colonial bourgeoisie depend on the presence of servants who share their knowledge and navigate the spaces that their employers cannot reach. The intertwining of class and race, and the operation of ethnic classism, or Levantine classism, reveals how race is used to buttress class barriers and vice versa. This colonial legacy continues to operate in a wide range of representations, such as the historicization of the Egyptian past and the framing of cosmopolitanism, Levantinism, and Levantine culture.

\section{NOTES}

Author's note: Many thanks to Olga Greco, Nancy Linthicum, Lina Newton, Elazar Elhanan, Jeffrey Culang, and the fellows at the Faculty Fellowship Publication Program (FFPP) for their valuable feedback and comments.

${ }^{1}$ Throughout the article I refer to the author as Jacqueline Kahanoff.

${ }^{2}$ Jacqueline Shohet Kahanoff, Jacob's Ladder (London: Harvill Press, 1951), 180.

${ }^{3}$ For clarity, I have followed the spelling of Arabic names used in the novel.

${ }^{4}$ For examples of these memoirs, see n. 19.

${ }^{5}$ Genesis (28:11-19). "And he dreamed, and behold a ladder set up on the earth, and the top of it reached to heaven: and behold the angels of God ascending and descending on it. And, behold, the LORD stood above it, and said, I am the LORD God of Abraham thy father, and the God of Isaac: the land whereon thou liest, to thee will I give it, and to thy seed; And thy seed shall be as the dust of the earth, and thou shalt spread abroad to the west, and to the east, and to the north, and to the south: and in thee and in thy seed shall all the families of the earth be blessed."

${ }^{6}$ See Joel Beinin, The Dispersion of Egyptian Jewry (Berkeley, Calif.: University of California Press, 1998), 60-89.

${ }^{7}$ Nancy Y. Reynolds, "Sharikat al-Bayt al-Misri: Domesticating Commerce in Egypt, 1931-1956," Arab Studies Journal, 7-8 (1999-2000): 85; Reynolds, A City Consumed: Urban Commerce, The Cairo Fire, and the Politics of Decolonization in Egypt (Stanford, Calif.: Stanford University Press, 2012), 210.

${ }^{8}$ For more on Jacqueline Kahanoff, see Deborah Starr and Sasson Somekh, "Editors' Introduction," in Mongrels or Marvels: The Levantine Writings of Jacqueline Shohet Kahanoff, ed. Deborah Starr and Sasson Somekh (Stanford, Calif.: Stanford University Press, 2011), xiii-xv; Gil Hochberg, "'Permanent Immigration”: Jacqueline Kahanoff, Ronit Matalon, and the Impetus of Levantinism,” Boundary 32 (2004): 221; and Ammiel Alcalay, Keys to the Garden: New Israeli Writing (San Francisco, Calif.: City Light Books, 1996), 18.

${ }^{9}$ Starr and Somekh, "Editors' Introduction," xiv.

${ }^{10}$ See Evelyn Baring, Modern Egypt, vol. 2 (New York: Macmillan, 1908). 
${ }^{11}$ Hala Halim, Alexandrian Cosmopolitanism: An Archive (Bronx, N.Y.: Fordham University Press, 2013), 199-200; Maxime Du Camp, Souvenirs d'Egypte (Paris: Hachette, 1892), 118-40. See also the Levantine character of Sabatini in Emile Zola, L'argent (Paris: Flammarion, 2009).

${ }^{12}$ Jacqueline Shohet Kahanoff, "Afterword," in Mongrels or Marvels, 247; Gil Hochberg, In Spite of Partition: Jews, Arabs and the Limits of Separatist Imagination (Princeton, N.J.: Princeton University Press, 2007), 45-50.

${ }^{13}$ Ella Shohat, "Rupture and Return: Zionist Discourse and the Study of Arab Jews," Social Text 21 (2003): 49-52. On the Egyptian context, see Gudrun Krämer, "The Beginning of the End," in The Jews in Modern Egypt 1914-1952 (London: I.B.Tauris, 1989), 205-21.

${ }^{14}$ Ella Shohat, "Dislocated Identities; Reflections by an Arab Jew," Against the Current 8 (2003): 1.

${ }^{15}$ Shohat, Israeli Cinema: East/West and the Politics of Representation (London: I.B.Tauris, 2010), 106-7.

${ }^{16}$ Ibid., 9. Shohat provides a survey of Israeli films in which "ethnic/class division is presented . . . as natural and inevitable." Arab Jews are Orientalized and presented as either domestic help or humble workers, while Ashkenazi Jews are portrayed as leaders and intellectuals. Quote from pp. 119-20. On the same subject, Ammiel Alcalay, quoting Trinh Min-ha, explains: "In Israel, the Jewish labourer is Oriental despite the fact that he was born to parents who in all likelihood were not employed as labourers . . . He is Oriental because . . . [he] is representative of his 'race'-the ethnic group as a whole." As quoted in Ammiel Alcalay, After Jews and Arabs: Remaking Levantine Culture (Minneapolis, Minn.: University of Minnesota Press), 26.

${ }^{17}$ Starr and Somekh, "Editors' Introduction," xii.

${ }^{18}$ Jacqueline Shohet Kahanoff, Jacob's Ladder (London: Harvill Press, 1951), 247.

${ }^{19}$ Alcalay, Keys to the Garden, v-vi.

${ }^{20}$ For recent documentaries produced in Egypt on Egyptian Jews and foreign minorities, see Salata Baladi, directed by Nadia Kamel (Cairo: Women Make Movies, 2007); Jews of Egypt, direted by Amir Ramsis (Cairo: Session, 2012); and That Alexandria, dir. Sherif Fathi Salem (Alexandria, Spot1tv and Aljazeera Documentary Channel, 2013). See also the Egyptian television series Harat al-Yahud, dir. Mohamed Gamal El Adl and Mahmoud Zahran (Cairo, El Adl Group, 2015). For novels from Egypt, see Ibrahim Abdel Meguid, No One Sleeps in Alexandria (Cairo: American University in Cairo Press, 2006); and Mo'taz Fetiha, Akhir Yahud al-Iskandariyya (Cairo: Oktob, 2009). For books on Cairo and Alexandria's urban history, see Robert Ilbert, Alexandria 1860-1960: A Brief Life of a Cosmopolitan Community, ed. Robert Ilbert, Ilios Yannakakis, and Jacques Hassoun, trans. Colin Clement (Alexandria: Harpocrates, 2007); and Samir Raafat, Cairo, the Glory Years: Who Built What, Why and for Whom (Alexandria: Harpocrates, 2005). From Israel, see Moshe Sakal, Yolanda, trans. Valérie Zenatti (Paris: Stock, 2012); and Ronit Matalon, The One Facing Us, trans. Marsha Weinstein (New York: Holt, 1995). For novels from France, see Paula Jacques, Gilda Stambouli souffre et se plaint (Paris: Mercure de France, 2002). For further examples, see n. 24.

${ }^{21}$ I draw on Ann Laura Stoler's analysis of the "politics of memory" in the memoirs of elites from colonial Java, which often represent domestics in a romantic, nostalgic light. This representation contradicts the account of the actual workers who served in colonial houses. Ann Laura Stoler, Carnal Knowledge and Imperial Power: Race and the Intimate in Colonial Rule (Berkeley, Calif., and Los Angeles: University of California Press, 2002), 24.

${ }^{22}$ See, for instance, Deborah Starr, Remembering Cosmopolitan Egypt: Literature, Culture and Empire (London: Routledge, 2009); Starr, "Drinking, Gambling, and Making Merry: Waguih Ghali's Search for Cosmopolitan Agency," Middle Eastern Literatures 9 (2006): 271-85; Hochberg, In Spite of Partition; and Lital Levy, Poetic Trespass Writing between Hebrew and Arabic in Israel/Palestine (Princeton, N.J.: Princeton University Press, 2014), 4.

${ }^{23}$ Khaled Fahmy, "The Essence of Alexandria," Manifesta Journal 14 (2009): 65-72; Halim, Alexandrian Cosmopolitanism, 8; Robert Mabro, "Nostalgic Literature on Alexandria," in Historians in Cairo: Essays in Honor of George Scanlon, ed. Jill Edwards (Cairo: American University in Cairo Press, 2002), 251; Deborah Starr, Remembering Cosmopolitan Egypt; Dario Miccoli, Histories of the Jews of Egypt: An Imagined Bourgeoisie, 1880s-1950s (New York: Routledge, 2015), 54.

${ }^{24}$ Gudrun Krämer, The Jews in Modern Egypt, 8-67; Mabro "Nostalgic Literature on Alexandria," 238.

${ }^{25}$ See, for instance, André Aciman, Out of Egypt (New York: Farrar, Straus and Giroux, 1994); Paula Jacques, Lumière de l'oeil (Paris: Mercure de France, 1980); Victor Teboul, La lente découverte de l'etrangeté (Montréal: Les intouchables, 2002); and Naguib Mahfouz, Miramar (New York: Anchor Books, 1978). Mahfouz describes Zohra, a rural woman who works in an Alexandrian bed and breakfast, as an embodiment of a modern Egypt coveted by the different hotel guests. 


\section{Amr Kamal}

${ }^{26}$ Pierre Bourdieu, Outline of Theory of Practice (Cambridge: Cambridge University Press, 1977), 78-79.

${ }^{27}$ Ann McCLintock, Imperial Leather: Race, Gender and Sexuality in the Colonial Context (New York: Routledge, 1995), 52-54. McClintock introduces the concept of "commodity racism" to analyze the connection between consumerism and the representation of race and gender. She also analyzes the portrayal of the English and Irish working class and its representation as colonial subjects to be civilized.

${ }^{28}$ Ibid., 36.

${ }^{29}$ See, for instance, Gil Anidjar, The Jew, the Arab: A History of the Enemy (Stanford, Calif.: Stanford University Press, 2003), xii-xvii. Anidjar delineates the different colonial legal strategies of classification that distinguish between native and nonnative colonial subjects.

${ }^{30}$ My notion of "ethnic classism," especially the connection to the civilizing mission and the ambiguous representation of labor in metropole and colonial subjects, draws and elaborates on Ann McCLintock's concept of "commodity racism" and Mona Domosh's idea of "flexible racism." For the latter, see Mona Domosh, Commodities in an Age of Empire (New York: Routledge, 2006), 181-94. Domosh explores the connection between 19th- and early 20th-century racial representation in American society and consumerism, as evidenced in the commercial advertising created for international markets which promoted the idea that the use of American products embodies the promise of becoming "white through consumption." Domosh, Commodities, 189.

${ }^{31}$ Ann Laura Stoler and Carole McGranahan, "Reconfiguring Imperial Terrains," in Imperial Formations, ed. Ann Laura Stoler, Carole McGranahan, and Peter C. Perdue (Santa Fe, N.Mex.: School of Advanced Research Press, 2007), 8.

${ }^{32}$ These complex connections have been at the center of recent studies on Egypt's colonial history. See, for instance, Wilson Chacko Jacob, Working out Egypt: Effendi Masculinity and Subject formation in Colonial Modernity, 1870-1940 (Durham, N.C.: Duke University Press, 2011), 6; and Ziad Fahmy, Creating the Modern Nation through Popular Culture (Stanford, Calif.: Stanford University Press, 2011).

${ }^{33}$ Stoler and McGranahan, "Reconfiguring Imperial Terrains," in Imperial Formations, 8.

${ }^{34}$ Krämer, The Jews of Modern Egypt, 38.

${ }^{35}$ Ibid., 9.

${ }^{36}$ Ann Laura Stoler and Frederick Cooper, "Between Metropole and Colony, Rethinking a Research Agenda," in Tensions of Empire: Colonial Cultures in a Bourgeois World, ed. Ann Laura Stoler and Frederick Cooper (Berkeley, Calif.: University of California Press, 1997), 6.

${ }^{37}$ Kahanoff, Jacob's Ladder, 3. A habāra is a traditional veil worn mostly by elite and middle-class Egyptian women during the late 19 th and early 20 th centuries.

${ }^{38}$ Ibid., 14.

${ }^{39}$ Edward Said, Orientalism (New York: Vintage Books, 1979), 112. Said invokes Benjamin Disraeli’s novel Tancred to expose the collusion between the ethnic representation of Jews and Arabs: "Arabs are simply Jews on horseback, and all are Orientals at heart." See also Gil Anidjar, Semites (Stanford, Calif.: Stanford University Press, 2008), 28, 33. Anidjar elaborates on what he terms the "Semitic hypothesis," that is, the European creation of the ethnic marker "Arab" and the religious marker "Jew." He demonstrates how in these particular classifications of the Semitic race, ethnic and religious markers collide.

${ }^{40}$ Kahanoff, Jacob's Ladder, 4.

${ }^{41}$ Stoler, Carnal Knowledge, 133.

${ }^{42}$ Kahanoff, Jacob's Ladder, 22.

${ }^{43}$ The connection between the store and French material culture is based on Kahanoff's memory of her grandparents' actual department store in Cairo, Chemla frères. Like many similar establishments in Egypt, Chemla frères contributed to the celebrated, Francophone and cosmopolitan Egyptian lifestyle. The actual Chemla store was built in "a "fin de siècle French style." Having an office in Paris, the store imported and produced Parisian style goods. Reynolds adds that "The Chemlas' status as French subjects and their familiarity with French culture and commerce traced back to their origins in French-occupied Tunisia." Reynolds, A City Consumed, 58-59.

${ }^{44}$ Kahanoff, Jacob's Ladder, 25.

${ }^{45}$ Ibid., 23.

${ }^{46}$ Ibid., 57.

${ }^{47}$ Ibid., 135.

${ }^{48} \mathrm{On}$ the relation between gender, class, and consumerism in colonial Egypt, see Mona Russell, Creating the New Egyptian Woman: Consumerism, Education, and National Identity, 1863-1922 (New York: Palgrave, 
2004), 79, 95; Reynolds, A City Consumed; and Jacob, Working Out Egypt. Russell examines the phenomenon and image of al-sayyida al-istihläkiyya, or Mrs. Consumer, and her position within Egyptian feminist and nationalist discourse. Jacob's Ladder, however, presents a different perspective based on the actual experience of a family that worked in commerce and its impact on social and gender roles. It also reveals the ambiguous situation of that family, which, despite its role in recreating the image of the middle class, still found itself in a liminal space between the culture of the colonial bourgeoisie and that of emerging Egyptian nationalism.

${ }^{49}$ Kahanoff, Jacob's Ladder, 421.

${ }^{50}$ Ibid., 28, 30.

${ }^{51}$ Ibid., 116.

${ }^{52}$ Pierre Bourdieu, Distinction: A Social Critique of Judgment of Taste, trans. Richard Nice (Cambridge, Mass.: Harvard University Press, 1984), 60.

${ }^{53}$ Ann Laura Stoler and Frederick Cooper, "Between Metropole and Colony: Rethinking a Research Agenda," in Tensions of Empire, 6.

${ }^{54}$ Said, Orientalism, 41.

${ }^{55}$ Michel Foucault, Discipline and Punish, trans. Alan Sheridan (New York: Vintage, 1995), 231.

${ }^{56}$ Kahanoff, Jacob's Ladder, 180.

${ }^{57}$ Ibid., 159-60.

${ }^{58}$ Ibid., 209.

${ }^{59}$ Ibid., 161.

${ }^{60}$ Ibid., 167.

${ }^{61}$ Frantz Fanon, Black Skin, White Masks, trans. Richard Philcox (New York: Grove, 1967).

${ }^{62}$ William E. B. Dubois, The Souls of Black Folk (Boston: Bedford, 1997), 38. Dubois describes his realization of racial difference as follows: "Then it dawned upon me with a certain suddenness that I was different from the others; or like [them perhaps] in heart and life and longing, but shut out from their world by a vast veil. I had thereafter no desire to tear down that veil, to creep through; I held all beyond it in common contempt, and lived above it in a region of blue sky and great wandering shadows." Kahanoff's language and metaphor of the veil strongly resemble those of Dubois. Her likely allusion to Dubois hints at the influence of her educational experience in the United States. See Starr and Somekh, "Editors' Introduction," xvi.

${ }^{63}$ See McClintock, Imperial Leather, 52. In her study of English printed media, McClintock shows how the Irish were portrayed in a racialized manner to resemble colonial subjects.

${ }^{64}$ Kahanoff, Jacob's Ladder, 167-68.

${ }^{65}$ Ibid., 170.

${ }^{66}$ Ibid., 211. Italics in original.

${ }^{67}$ Ibid., 422. Janet Abu-Lughod, Cairo: 1001 Years of the City Victorious (Princeton, N.J.: Princeton University Press, 1971), 142.

${ }^{68}$ Kahanoff, Jacob's Ladder, 178.

${ }^{69}$ As a young woman, Kahanoff and some of her friends volunteered in a clinic in härat al-yahüd. Most likely she is aware of the neighborhood's human and cultural geography, which is different from Alice's and Miss Nutting's reductive classist and colonial perspectives. See Starr and Somekh, "Editors' Introduction," xv; and Deborah Starr, "Sensing the City: Representations of Cairo's Harat al-Yahud," 26, 138-62. See also the television series Harat al-Yahud (2015).

${ }^{70}$ Kahanoff, Jacob's Ladder, 399.

${ }^{71}$ Ibid., 400.

${ }^{72}$ Ibid., 364.

${ }^{73}$ Ibid., 364, 366.

${ }^{74} \mathrm{Miccoli}$, Histories of the Jews of Egypt, 70.

${ }^{75}$ Kahanoff, Jacob's Ladder, 349.

${ }^{76}$ Ibid. Jacqueline Kahanoff alludes here to the French expression "Our ancestors the Gauls" typically used in French history books, and ironically included in the curricula used for Francophone colonial subjects, who obviously cannot identify with that foundational narrative.

${ }^{77}$ Ibid., 394.

${ }^{78}$ Ibid., 424.

${ }^{79}$ Ernest Klein, A Comprehensive Etymological Dictionary of the Hebrew Language for Readers of English (Haifa: Carta Jerusalem, 1987), 435-36.

${ }^{80}$ Kahanoff, Jacob's Ladder, 417. 